\title{
Rice and rice bran from different cultivars: physicochemical, spectroscopic, and thermal analysis characterization
}

\section{Arroz e farelo de arroz de diferentes cultivares: caracterização físico-química, por espectroscopia e análise térmica}

\author{
Daneysa Lahis Kalschne ${ }^{1}$; Rosana Aparecida da Silva-Buzanello²; \\ Ana Paula Iglikowski Byler ${ }^{3}$; Fernando Reinoldo Scremin ${ }^{4}$; \\ Ariano Martins de Magalhães Junior ${ }^{5}$; Cristiane Canan ${ }^{6 *}$
}

\begin{abstract}
Highlights:
The protein, carbohydrate, and phytic acid content varied in white rice cultivars. Moisture, ash, and lipids had similar content in distinct white rice cultivars.

The physicochemical parameters differ in rice bran from different cultivars studied.

The white rice and rice bran had chemical composition different for each cultivar.

FTIR-ATR and thermal analyses confirmed the differences of white rice and rice bran.
\end{abstract}

\begin{abstract}
Different rice cultivars have been developed in order to obtain grains with optimal cultivation and compositional characteristics, which affect their potential applications. Therefore, the characterization of these different rice cultivars is required. In the present study, white rice and rice bran from the cultivars BRS AG, BRS Pampa, and BRS 358 provided by EMBRAPA were characterized by physicochemical means, infrared spectroscopy (FTIR-ATR), and thermal analyses. The moisture, lipid, and ash contents did not differ among the white rice cultivars. The cultivar BRS Pampa exhibited the highest protein and lowest total carbohydrate contents. Both BRS Pampa and BRS 358 showed a higher phytic acid content than BRS AG. The highest total carbohydrate content was observed in BRS AG white rice samples, which confirmed its suitability for use in ethanol production. Among the rice bran samples, BRS 358 demonstrated the highest contents of lipid, protein, and phytic acid, and the lowest total carbohydrate content. FTIR-ATR and thermal analyses were suitable for correlating the physicochemical properties of white rice and rice bran with the molecular composition in the respective cultivars studied. Both white rice and rice bran exhibited a thermal degradation temperature at $300{ }^{\circ} \mathrm{C}$. Lipids, protein, ash and phytic acid were considerably higher in rice bran than white rice in all cultivars studied, which demonstrates the importance of the use of this by-product.
\end{abstract}

Key words: BRS AG. BRS Pampa. BRS 358. Irrigated rice. Oryza sativa.

1 Pós-Doutoranda do Programa de Pós-Graduação em Tecnologia de Alimentos, Departamento de Alimentos, Universidade Tecnológica Federal do Paraná, UTFPR, Medianeira, PR, Brasil. E-mail: daneysa@hotmail.com

2 Profa, Curso de Graduação em Engenharia e Tecnologia de Alimentos, Departamento de Alimentos, UTFPR, Medianeira, PR, Brasil. E-mail: rosanabuzanello@gmail.com

3 Discente do Programa de Pós-Graduação em Tecnologia de Alimentos, Departamento de Alimentos, UTFPR, Medianeira, PR, Brasil. E-mail: anapaulabylerr@outlook.com

4 Pós-Doutorando do Programa de Pós-Graduação em Tecnologias Ambientais, Departamento de Química, UTFPR, Medianeira, PR, Brasil. E-mail: screminfr@gmail.com

5 Pesquisador, Empresa Brasileira de Pesquisa Agropecuária, EMBRAPA Clima Temperado, Pelotas, RS, Brasil. E-mail: ariano. martins@embrapa.br

${ }^{6}$ Profa, Programa de Pós-Graduação em Tecnologias Ambientais, Departamento de Química, UTFPR, Medianeira, PR, Brasil. E-mail: canan@utfpr.edu.br

* Author for correspondence 


\title{
Resumo
}

\begin{abstract}
Várias cultivares de arroz tem sido desenvolvida no intuito de obter grãos com características de cultivo e composição apropriadas, que são responsáveis pela indicação de uso/consumo dos grãos. Assim, justifica-se a necessidade de caracterização das diferentes cultivares de arroz. No presente estudo, o arroz branco e o farelo de arroz das cultivares BRS AG, BRS Pampa, e BRS 358, cedidas pela EMBRAPA, foram caracterizadas a partir de análises físico-químicas, espectroscopia no infravermelho (FTIR-ATR) e análises térmicas. Nas amostras de arroz branco, o conteúdo de umidade, lipídios e cinzas não diferiu entre as cultivares. A BRS Pampa teve o maior teor de proteínas e o menor teor de carboidratos. A BRS Pampa e BRS 358 tiveram maior teor de ácido fítico. O maior conteúdo de carboidratos observado no arroz branco da cultivar BRS AG confirma sua indicação de uso na produção de bioetanol. Nas amostras de farelo de arroz, a BRS teve maior teor de lipídios, proteínas e ácido fítico, e o menor de carboidratos totais. A análise por FTIR-ATR e análise térmica permitiram correlacionar as propriedades físico-químicas do farelo de arroz e arroz branco com a composição química dentro de cada cultivar estudada. $\mathrm{O}$ arroz branco e o farelo de arroz exibiram degradação térmica a $300{ }^{\circ} \mathrm{C}$. O conteúdo de lipídios, proteínas, cinzas e ácido fítico foram superiores no farelo em comparação ao arroz branco para todas as cultivares, o que demonstra a importância do uso desse subproduto.
\end{abstract}

Palavras-chave: Arroz irrigado. BRS AG. BRS Pampa. BRS 358. Oryza sativa.

\section{Introduction}

Brazil is the largest producer and a leader in rice cultivation (Oryza sativa) of Mercosul. In the 2017/2018 harvest, Brazilian rice production was 10.5 thousand tons from a cultivated area of 1,679 hectares. The southern region of Brazil is the national leader in productivity $\left(6.3 \mathrm{~kg} \mathrm{ha}^{-1}\right)$ and production (10,510 thousand tons) (CONAB, 2020). Rice cultivation is relevant to social and governmental actions and incentives related to its cultivation to ensure supply and consumption levels, with emphasis on the poorest classes of the population, who normally consume rice as a dietary staple (O. F. Silva 2019a).

The quality of rice produced in Brazil is recognized worldwide; Brazilian rice is mainly destined for human consumption in grain form (SNA, 2017; Walter, Marchezan, \& Avila, 2008). According to Brazilian standards, high-quality rice is characterized by long and thin grains (from Portuguese "agulhinha") with translucent aspects, polished and free of foreign matter, and is loose, dry, and soft after cooking (Castro, Castro, \& Morais, 2013). Rice leads the most consumed food groups in Brazil of consumers (Souza et al. 2013), with a per capita consumption of polished rice (whole grains) of $32.0 \mathrm{~kg} /$ inhabitant (Silva 2019b). It is considered an excellent energy source due the high starch concentration, also supplying proteins, vitamins and minerals, with a low lipid content (Walter et al., 2008). Among the types of rice, more than $70 \%$ of Brazilians prefer white rice, followed by parboiled (25\%) and whole (from $3 \%$ to $4 \%$ ) (CONAB, 2015).

In white rice procurement, the grain is subjected to the dehulling process, which is followed by polishing (Bragantini \& Eifert, 2013). Rice bran is a by-product obtained during polishing, composed of the pericarp, aleurone, and germ (Canan et al., 2011). Rice bran represents from $17.59 \%$ to $24.75 \%$ of the total grain weight (Moongngarm, Daomukda, \& Khumpika, 2012) and, in Brazil, is mainly employed in animal feed (Bragantini \& Eifert, 2013; Gomes et al., 2012). However, more recent research has been carried out aimed at the use of bioactive compounds and fractions of interest of rice bran, due to its potential use as an antioxidant, as a prebiotic, in the production of bioethanol, and as a microencapsulating and nanoencapsulating agent (Canan et al., 2011; Demirci, Aktaş, Sözeri, 
Öztürk, \& Akın, 2017; Favaro et al., 2017; Huang \& Lai, 2016; C. Liu et al., 2017a; Michel et al., 2016; Scremin et al., 2017).

With the advancement of genetic engineering, several new rice cultivars have been developed. Many factors are considered in the choice of a cultivar, among them the cultivation system (irrigated or upland), water availability, cultivar characteristics (cycle, plant height, resistance to diseases, tolerance to water stress, product quality, and productivity), recommendation for a given region and availability of certified seeds, technology employed, soil fertility, and planting system (Castro et al., 2013; Streck, Bosco, Michelon, Walter, \& Marcolin, 2006).

The Brazilian Agricultural Research Corporation (EMBRAPA) has been working for years on developing rice cultivars with different applications, and among them there are the irrigated cultivars BRS AG, Pampa BRS, and BRS 358. The cultivar BRS AG was developed mainly for use as a raw material in ethanol production or animal feed. The cultivar produces a grain of large size and has a medium-cycle (126 days) and average height. The cultivar BRS Pampa presents high productive potential, a short-cycle (up to 115 days), resistance to major diseases, and excellent cooking attributes such as a loose and soft texture after cooking. The cultivar BRS 358 was developed for Japanese cooking, presenting a low amylose content and an intermediate gelatinization temperature. This cultivar has a medium-cycle (125 days), medium stature, and good resistance to diseases (Empresa Brasileira de Pesquisa Agropecuária [EMBRAPA], 2015).

Regarding these new cultivars, it is crucial to know their properties in order to indicate potential uses. In this context, the aim of this study was to characterize white rice and rice bran from three cultivars (BRS AG, BRS Pampa, and BRS 358) developed by EMBRAPA, in terms of their chemical, physicochemical, and thermal properties.

\section{Material and Methods}

Three rice cultivars (BRS AG, BRS Pampa, and BRS 358) were cultivated at the Brazilian Agricultural Research Corporation (EMBRAPA)/ Temperate Climate Center - Pelotas, Rio Grande do Sul, Brazil, under identical conditions. When the grains matured, the rice grain was harvested and submitted to the dehulling and polishing process using a rice processor (Rural ZX-3, Zaccaria, São Paulo) to obtain white rice and rice bran. The rice bran was subjected to milling (sieve size $1.18 \mathrm{~m}$ ) in a knife mill (model SL31, Solab, Piracicaba, Brazil). The samples were stored in plastic bags at $-18{ }^{\circ} \mathrm{C}$.

Color parameters were determined using a Minolta CR400 colorimeter (Konica Minolta, New Jersey, USA) with a D illuminant and a $45^{\circ}$ standard observer. Moisture content was determined by gravimetric measurement after drying in an oven (model Q317M, Quimis, São Paulo, Brazil) at $105 \pm$ $2{ }^{\circ} \mathrm{C}$. Protein content was performed by the Kjeldahl method. The samples were digested (digester block model 040125 and temperature controller model TE-007MP, Nova Técnica, Piracicaba, Brazil), and the nitrogen was distillated in a Kjeldahl apparatus (model NT 415, Nova Técnica, Piracicaba). A nitrogen conversion factor of 5.95 is indicated for rice (Instituto Adolfo Lutz [IAL], 2005) and was employed to determine the total protein content. The lipid content was determined by hot extraction (oil and fat extractor model MA419, Marconi, São Paulo, Brazil) using hexane. Ash content was determined by calcination in an oven (Jung, São Paulo) at $550{ }^{\circ} \mathrm{C}$ for $6 \mathrm{~h}$ or until light ash was obtained. Total carbohydrates were calculated by difference (Huang \& Lai, 2016; Smanalieva, Salieva, Borkoev, Windhab, \& Fischer, 2015).

Phytic acid determination was adapted from Canan et al. (2011). The samples ( $0.8 \mathrm{~g}$ of white rice and $0.25 \mathrm{~g}$ of rice bran) were extracted with $1 \mathrm{M} \mathrm{HCl}$ (10 mL), assisted by $2 \mathrm{~min}$ of ultrasound, with $40 \%$ power and a frequency of $80 \mathrm{kHz}$. The supernatant was centrifuged ( $2000 \mathrm{~g}$ for $20 \mathrm{~min}$ ) and diluted with 
distilled water. Ion exchange chromatography with a glass column containing $0.6 \mathrm{~g}$ of Dowex-AGX-4 resin, previously prepared by elution with distilled water $(10 \mathrm{~mL}), 0.7 \mathrm{M} \mathrm{NaCl}(10 \mathrm{~mL})$ and distilled water $(10 \mathrm{~mL})$, were employed. The supernatant was applied and eluted with $0.1 \mathrm{M} \mathrm{NaCl}(10 \mathrm{~mL})$ and $1 \mathrm{M} \mathrm{NaCl}(10 \mathrm{~mL})$. The last eluted $(10 \mathrm{~mL})$ was collected and the Wade reactive was added to the eluent $(3 \mathrm{~mL})$ and analyzed in a spectrophotometer $(500 \mathrm{~nm})$.

White rice and rice bran were submitted to Fourier transform infrared (FTIR) spectroscopy analysis (model Spectrum 100S, PerkinElmer, Beaconsfield, United Kingdom) in attenuated reflectance mode (ATR). FTIR-ATR spectra were obtained in the wavenumber range from 4000 to $600 \mathrm{~cm}^{-1}$ during 10 scans with $4 \mathrm{~cm}^{-1}$ resolution.

The thermogravimetric analyses measurements were taken using a thermo-analyzer STA 6000 (PerkinElmer, Beaconsfield, United Kingdom). Each sample (from 12 to $18 \mathrm{mg}$ ) was placed in a non-hermetic platinum crucible and heated from 50 to $600{ }^{\circ} \mathrm{C}$, at a heating rate of $10^{\circ} \mathrm{C}$ $\mathrm{min}^{-1}$ under a nitrogen atmosphere of $20 \mathrm{~mL} \mathrm{~min}^{-1}$.

\section{Results and Discussion}

Regarding visual characteristics, especially the BRS AG white rice had a peculiar format (Figure 1). For white rice and rice bran, the BRS AG cultivar had the highest luminosity, and the $\mathrm{a}^{*}$ value was lower than that of other cultivars $(p \leq 0.05)$. The $b^{*}$ value was higher in BRS 358 than in BRS AG for white rice and rice bran $(\mathrm{p} \leq 0.05)$ (Table 1$)$. Values between 66.2 and 85.2 for $L^{*}$, from -1.38 to 5.24 for $a^{*}$, and from 7.60 and 19.10 for $b^{*}$ were reported in the literature for white rice (Adu-Kwarteng, Ellis, Oduro, \& Manful, 2003; Paraginski, Ziegler, Talhamento, Elias, \& Oliveira, 2014; Tran, Okadome, Murata, Homma, \& Ohtsubo, 2001; Zanão, Canniatti-Brazaca, Sarmento, \& Arthur, 2009). L* values obtained in the present study were higher than that observed in the literature, and $b^{*}$ values were lower, characteristics of lighter samples. For rice bran, information about color parameters are scarce, and the values obtained for $\mathrm{L}^{*}$ and $\mathrm{b}^{*}$ were higher, and for $\mathrm{a}^{*}$, lower than reported by Choi et al. (2011). However, light and yellow color predominance was observed, evidenced by high luminosity and a positive value of $b^{*}$ (Table 1 ). Variations observed compared with literature data can be correlated with cultivars, cropping regions, agricultural practices, post-harvest processing, and degree of polishing. These parameters are used by the industry to assess rice quality. The white color of rice grain presents a visual appeal and some consumers believe that white rice present higher quality (Adu-Kwarteng et al., 2003). For rice bran, color can be decisive for its application in food.

For white rice, the moisture, lipid, and ash contents did not differ $(p>0.05)$ among the rice cultivars. The protein content was higher in the BRS Pampa cultivar, followed by BRS 358 and BRS AG $(p \leq 0.05)$. The total carbohydrate content was higher in BRS AG followed by BRS 358 and BRS Pampa ( $\mathrm{p} \leq 0.05)$. The phytic acid content in BRS Pampa and BRS 358 cultivars were higher than that in BRS AG $(p \leq 0.05)$ (Table 1). The above cited values were similar to those reported in the literature for white rice (dry basis). A moisture content from

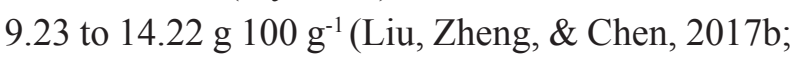
Silva, Ascheri \& Pereira, 2007; Smanalieva et al., 2015; Zanão et al., 2009), lipids from 0.13 to 1.05 g 100 g $^{-1}$ (Kaminski, Brackmann, Silva, Bender, \& Speroni, 2013; Liu et al., 2017b; Silva et al., 2007; Zanão et al., 2009), proteins between 8.30 and

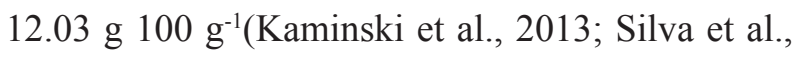
2007; Smanalieva et al., 2015; Walter et al., 2008), ash from 0.30 to $0.68 \mathrm{~g} 100 \mathrm{~g}^{-1}$ (Adu-Kwarteng et al., 2003; Liu et al., 2017b; Walter et al., 2008; Zanão et al., 2009), total carbohydrate between

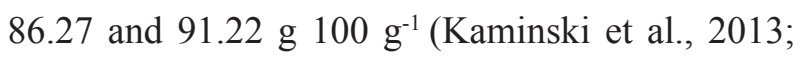
Silva et al., 2007; Smanalieva et al., 2015; Zanão et al., 2009), and phytic acid from 0.03 to $0.20 \mathrm{~g} 100$ 
$\mathrm{g}^{-1}$ (Liu et al., 2017b) were reported. The highest total carbohydrate content was observed in the BRS AG white rice, which justifies its indication of use in bioethanol production (EMBRAPA, 2015), as hydrolyzed starch is a fermentable substrate (Favaro et al., 2017).

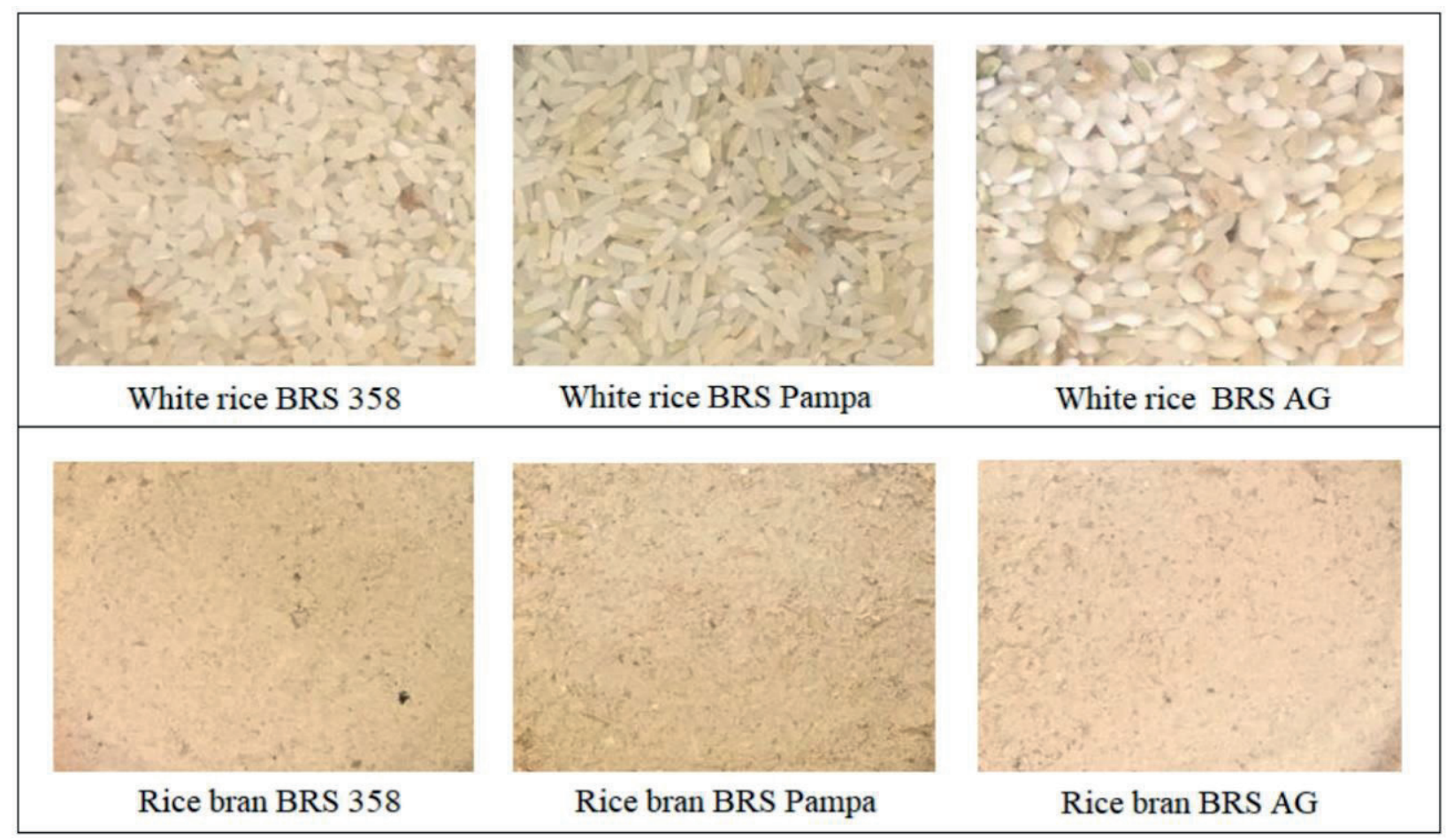

Figure 1. Visual characteristics of white rice and rice bran samples. 
Table 1

Physicochemical parameters of white rice and rice bran from different cultivars (dry basis)

\begin{tabular}{|c|c|c|c|c|c|c|c|c|c|}
\hline $\begin{array}{l}\text { Sam- } \\
\text { ples }\end{array}$ & $\mathrm{L}^{*}$ & $\mathrm{a}^{*}$ & $b^{*}$ & 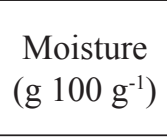 & $\begin{array}{c}\text { Lipid } \\
\left(\mathrm{g} 100 \mathrm{~g}^{-1}\right)\end{array}$ & $\begin{array}{c}\text { Protein } \\
\left({\left.\mathrm{g} 100 \mathrm{~g}^{-1}\right)}\right.\end{array}$ & $\begin{array}{c}\text { Ash } \\
\left(\mathrm{g} 100 \mathrm{~g}^{-1}\right)\end{array}$ & $\begin{array}{l}\text { Total car- } \\
\text { bohydrate } \\
\left(\mathrm{g} 100 \mathrm{~g}^{-1}\right)\end{array}$ & $\begin{array}{c}\text { Phytic } \\
\text { acid } \\
\left(\mathrm{g} 100 \mathrm{~g}^{-1}\right)\end{array}$ \\
\hline $\begin{array}{c}\text { Rice } \\
\text { BRS } \\
\text { AG }\end{array}$ & $\begin{array}{l}91.11 \\
\pm 0.24^{\mathrm{a}}\end{array}$ & $\begin{array}{l}-4.87 \\
\pm 0.01^{\mathrm{b}}\end{array}$ & $\begin{array}{c}11.73 \\
\pm 0.35^{\mathrm{c}}\end{array}$ & $\begin{array}{l}12.41 \\
\pm 0.15^{\mathrm{a}}\end{array}$ & $\begin{array}{c}0.76 \\
\pm 0.06^{\mathrm{a}}\end{array}$ & $\begin{array}{c}8.36 \\
\pm 0.05^{\mathrm{c}}\end{array}$ & $\begin{array}{c}0.34 \\
\pm 0.04^{\mathrm{a}}\end{array}$ & $\begin{array}{c}90.54 \\
\pm 0.02^{\mathrm{a}}\end{array}$ & $\begin{array}{c}0.03 \\
\pm 0.01^{\mathrm{b}}\end{array}$ \\
\hline $\begin{array}{c}\text { Rice } \\
\text { BRS } \\
\text { Pampa }\end{array}$ & $\begin{array}{c}87.39 \\
\pm 0.43^{b}\end{array}$ & $\begin{array}{l}-4.77 \\
\pm 0.03^{\mathrm{a}}\end{array}$ & $\begin{array}{c}13.06 \\
\pm 0.10^{\mathrm{b}}\end{array}$ & $\begin{array}{l}12.30 \\
\pm 0.29^{\mathrm{a}}\end{array}$ & $\begin{array}{c}0.83 \\
\pm 0.09^{\mathrm{a}}\end{array}$ & $\begin{array}{c}12.42 \\
\pm 0.27^{\mathrm{a}}\end{array}$ & $\begin{array}{c}0.30 \\
\pm 0.02^{\mathrm{a}}\end{array}$ & $\begin{array}{c}86.46 \\
\pm 0.16^{c}\end{array}$ & $\begin{array}{c}0.12 \\
\pm 0.01^{\mathrm{a}}\end{array}$ \\
\hline $\begin{array}{c}\text { Rice } \\
\text { BRS } \\
358\end{array}$ & $\begin{array}{c}87.10 \\
\pm 0.41^{\mathrm{b}}\end{array}$ & $\begin{array}{c}-4.74 \\
\pm 0.03^{\mathrm{a}}\end{array}$ & $\begin{array}{c}14.19 \\
\pm 0.25^{\mathrm{a}}\end{array}$ & $\begin{array}{c}12.12 \\
\pm 0.29^{\mathrm{a}}\end{array}$ & $\begin{array}{c}0.93 \\
\pm 0.09^{\mathrm{a}}\end{array}$ & $\begin{array}{c}11.21 \\
\pm 0.58^{\mathrm{b}}\end{array}$ & $\begin{array}{c}0.35 \\
\pm 0.03^{\mathrm{a}}\end{array}$ & $\begin{array}{c}87.61 \\
\pm 0.50^{\mathrm{b}}\end{array}$ & $\begin{array}{c}0.10 \\
\pm 0.01^{\mathrm{a}}\end{array}$ \\
\hline $\begin{array}{c}\text { Bran } \\
\text { BRS } \\
\text { AG }\end{array}$ & $\begin{array}{c}75.35 \\
\pm 0.32^{\mathrm{A}}\end{array}$ & $\begin{array}{l}-2.37 \\
\pm 0.17^{\mathrm{B}}\end{array}$ & $\begin{array}{c}21.83 \\
\pm 0.23^{\mathrm{C}}\end{array}$ & $\begin{array}{c}11.28 \\
\pm 0.14^{\mathrm{A}}\end{array}$ & $\begin{array}{c}10.40 \\
\pm 0.98^{\mathrm{B}}\end{array}$ & $\begin{array}{c}14.14 \\
\pm 0.10^{\mathrm{B}}\end{array}$ & $\begin{array}{c}5.40 \\
\pm 0.55^{\mathrm{B}}\end{array}$ & $\begin{array}{c}69.72 \\
\pm 0.77^{\mathrm{A}}\end{array}$ & $\begin{array}{c}5.48 \\
\pm 0.13^{\mathrm{B}}\end{array}$ \\
\hline $\begin{array}{c}\text { Bran } \\
\text { BRS } \\
\text { Pampa }\end{array}$ & $\begin{array}{c}70.28 \\
\pm 0.77^{\mathrm{B}}\end{array}$ & $\begin{array}{c}-0.97 \\
\pm 0.46^{\mathrm{A}}\end{array}$ & $\begin{array}{c}23.46 \\
\pm 0.40^{\mathrm{B}}\end{array}$ & $\begin{array}{c}10.61 \\
\pm 0.19^{\mathrm{B}}\end{array}$ & $\begin{array}{c}10.87 \\
\pm 0.81^{\mathrm{B}}\end{array}$ & $\begin{array}{c}13.26 \\
\pm 0.97^{\mathrm{B}}\end{array}$ & $\begin{array}{c}7.57 \\
\pm 0.78^{\mathrm{A}}\end{array}$ & $\begin{array}{c}68.30 \\
\pm 1.14^{\mathrm{A}}\end{array}$ & $\begin{array}{c}5.43 \\
\pm 0.07^{\mathrm{B}}\end{array}$ \\
\hline $\begin{array}{c}\text { Bran } \\
\text { BRS } \\
358\end{array}$ & $\begin{array}{c}69.41 \\
\pm 0.13^{\mathrm{B}}\end{array}$ & $\begin{array}{c}-0.56 \\
\pm 0.04^{\mathrm{A}}\end{array}$ & $\begin{array}{c}25.00 \\
\pm 0.22^{\mathrm{A}}\end{array}$ & $\begin{array}{c}10.75 \\
\pm 0.29^{\mathrm{AB}}\end{array}$ & $\begin{array}{c}14.99 \\
\pm 0.52^{\mathrm{A}}\end{array}$ & $\begin{array}{c}17.50 \\
\pm 0.16^{\mathrm{A}}\end{array}$ & $\begin{array}{c}7.37 \\
\pm 0.41^{\mathrm{A}}\end{array}$ & $\begin{array}{c}60.14 \\
\pm 1.01^{\mathrm{B}}\end{array}$ & $\begin{array}{c}7.03 \\
\pm 0.43^{\mathrm{A}}\end{array}$ \\
\hline
\end{tabular}

Mean \pm standard deviation; $\mathrm{n}=3$; Total carbohydrate (dry basis) $=100$ - lipid - protein - ash; different lowercase and capital letters indicate difference among rice and rice bran samples, respectively, by Tukey test $(\mathrm{p} \leq 0.05)$.

The moisture content of rice bran was higher in BRS AG than in BRS Pampa, whereas in BRS 358 , the value was intermediate and did not differ from the others. Lipid and protein contents were higher in BRS 358 than in the other two cultivars $(\mathrm{p} \leq 0.05)$. BRS AG had lipid and protein content similar to those of BRS Pampa. The ash content was significantly higher in BRS Pampa and BRS 358 compared with BRS AG. The carbohydrate content was higher in BRS AG and BRS Pampa cultivars. The phytic acid content was higher in BRS 358 and lower in BRS AG and BRS Pampa (Table 1).

The physicochemical results for rice bran were in the range reported in the literature (on a dry basis). Other authors demonstrated variations in moisture

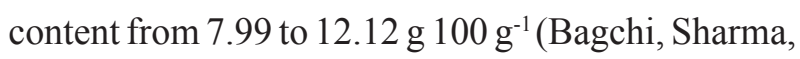
\& Chattopadhyay, 2016; Choi et al., 2011; Huang \& Lai, 2016; Rafe \& Sadeghian, 2017); in lipid from

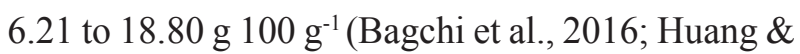

Lai 2016; Moongngarm et al., 2012; Moro, Rosa \&, Hoelzel, 2004); in protein from 12.07 to $16.53 \mathrm{~g} 100$ $\mathrm{g}^{-1}$ (Amagliani, O’Regan, Kelly, \& O'Mahony, 2017; Bagchi et al., 2016; Choi et al., 2011; Moongngarm et al., 2012; Rafe \& Sadeghian, 2017); in ash from 3.15

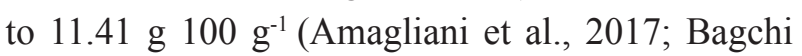
et al., 2016; Huang \& Lai, 2016; Moongngarm et al., 2012; Rafe \& Sadeghian, 2017); in carbohydrate

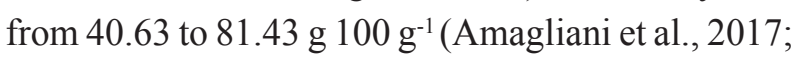
Huang \& Lai, 2016; Moongngarm et al., 2012; Moro et al., 2004); and in phytic acid from 2.57 to 7.08 g $100 \mathrm{~g}^{-1}$ (Canan et al., 2011; Moongngarm et al., 2012; Rafe \& Sadeghian, 2017). Wider variations in the composition of polished rice and rice bran are observed in the literature, considering different cultivars produced in regions with different farming practices. Furthermore, the composition of white rice and rice bran is influenced by the degree of polishing (Huang \& Lai, 2016; Liu et al., 2017b). 
In polished rice (BRS Pampa and BRS 358) and rice bran (BRS 358) samples, it was observed that cultivars with highest protein content also had the highest phytic acid content. This correlation is justified by the potential for phytic acid ionization and strong interactions with proteins and metal ions (Martinez, Martinez, Souza, \& Brazaca, 2011), although accumulation of nitrogen and phosphorus in the rice plant is an independent process (Liu, Cheng, Cheng, \& Zhang, 2005). In acidic pH and at low cation concentrations, a phytate-protein complex is formed due to direct electrostatic interactions, while at $\mathrm{pH}>6$ to 7 , a ternary phytic acid-mineralprotein complex is formed, which dissociates at high $\mathrm{Na}^{+}$concentrations. The complexes may be responsible for decreased bioavailability and are also more resistant to proteolytic digestion at low pH (Cheryan, 1980).

When white rice and rice bran samples were compared, it was observed that the carbohydrate content was higher in white rice, whereas the lipid, protein, ash, and phytic acid contents were higher in rice bran. These observations are explained by the maintenance of starchy endosperm and removal of the germ, pericarp, and aleurone in polished rice (CONAB, 2015). Lipids, proteins, and phytic acid are mainly concentrated in the germ and aleurone, while minerals are present in the grain external layer, justifying its high content of phytic acid (Bhatnagar, Prabhakar, Prasanth Kumar, Raja Rajan, \& Gopala Krishna, 2014; Canan et al., 2011; Liu et al., 2005; Walter et al., 2008). Phytic acid has a strong chelating capacity and was considered an antinutrient for many years, without any other properties currently attributed to this compound being discussed (Silva \& Bracarense, 2016). In recent years, the number of publications reporting the use of phytic acid has grown, especially its use in reducing the risk of diseases such as cancer (Masunaga et al., 2019), kidney stones (Saw, Chow,
Rao, \& Kavanagh, 2007), diabetes (Kim, Rico, Lee, \& Kang, 2010), and cardiovascular events (Fuster, Cortés, Bestard, \& Freixedas, 2017), and as an inhibitor of foodborne pathogens (Zhou, Zhao, Dang, Tang, \& Zhang, 2019).

Infrared spectroscopy analysis allows the identification of functional groups from the main molecules of samples, and the spectroscopic profile is directly correlated with the molecular composition of the samples studied. Variations in the spectroscopic behavior among white rice and rice bran were observed (Figure 2). Spectroscopic bands at approximately $2925 \mathrm{~cm}^{-1}$ and $2855 \mathrm{~cm}^{-1}$ are more intense and defined in rice bran samples. These bands are attributed to $\mathrm{CH}$-type molecular vibrations, and this fact can be explained by the higher lipid content present in rice bran (Table 1), since these molecules have carbon chains with a higher density of $\mathrm{CH}$ groups. Additionally, the spectroscopic band at $1640 \mathrm{~cm}^{-1}$ is slightly more intense in the spectra of rice bran samples, attributed to stretches of the $\mathrm{C}=\mathrm{O}$ group present in proteins. This band is named amide I, and its highest intensity is correlated to the higher protein content of rice bran (Table 1). Spectral bands at $1150 \mathrm{~cm}^{-1}$ and $1080 \mathrm{~cm}^{-1}$ preferentially appear in white rice samples, and they are related to $\mathrm{O}-\mathrm{C}-\mathrm{O}$ and $\mathrm{C}=\mathrm{O}$ stretches of glycosidic compounds, such as starch (Fan et al., 2012; Rubens \& Heremans, 2000; Ying et al., 2017) a waste stream from olive oil processing, was fractionated by centrifugation to obtain a supernatant and a flesh-enriched fraction, and freeze dried to obtain a powder. The dried supernatant contained $5.8 \%$ moisture, $4.8 \%$ protein, $3.5 \%$ fat, $3.5 \%$ ash, $82.4 \%$ carbohydrate (including $17.2 \%$ dietary fiber. This is expected in white rice because the grain is polished, presenting a high starch content (Table 1). Regarding the different cultivars, it is not possible to observe significant alterations between the spectra of white rice and rice bran. 


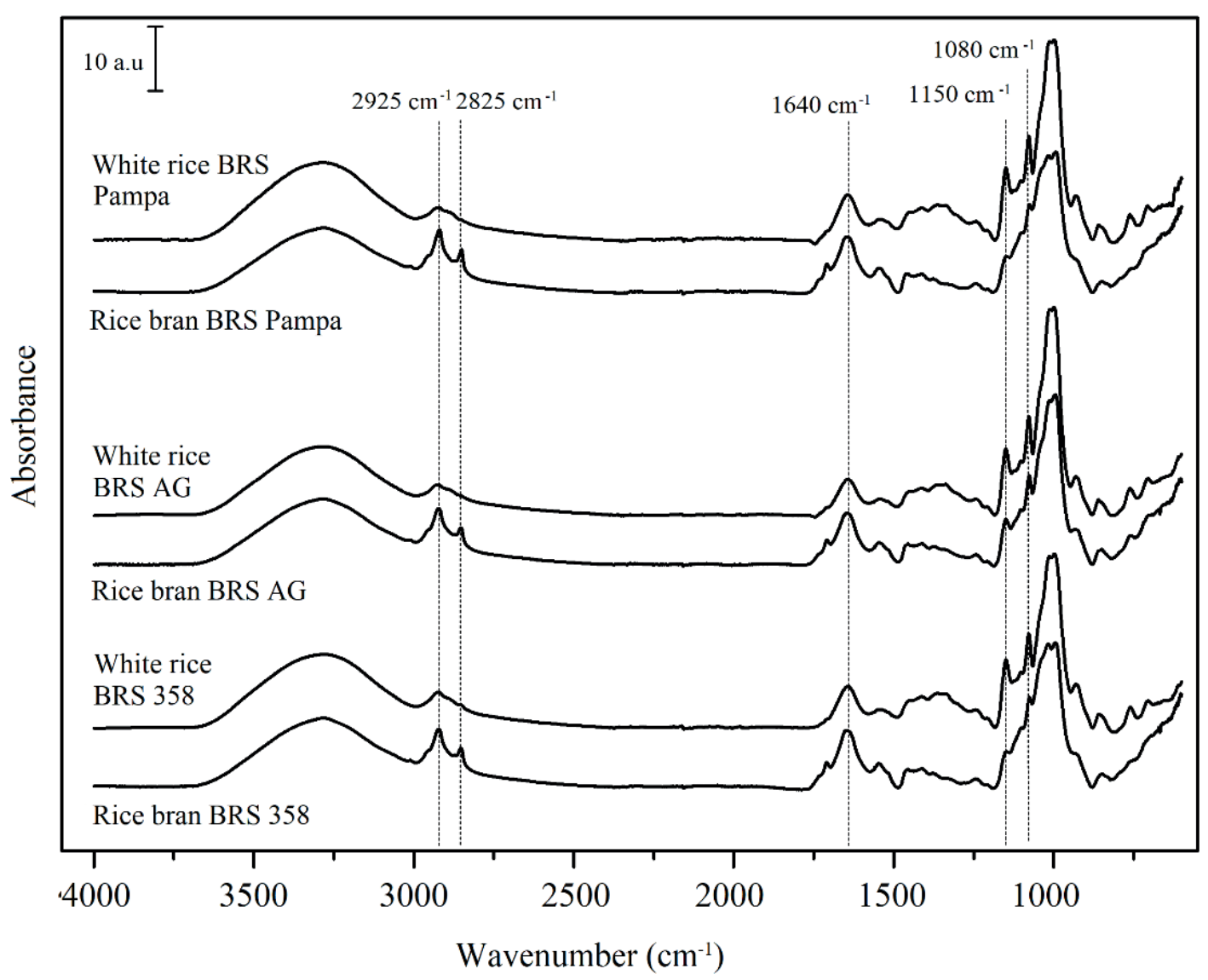

Figure 2. FTIR-ATR spectra of white rice and rice bran samples (4000-600).

Thermograms of white rice samples from different cultivars exhibited similar thermal behavior (Figure 3a). A mass loss of about $10 \%$ was observed at $120{ }^{\circ} \mathrm{C}$ for all rice cultivars, which could be related to sample water loss, corroborating the moisture values obtained (Table 1). Accentuated mass loss was observed above $300^{\circ} \mathrm{C}$ in all cultivars analyzed, which characterizes pyrolysis (Qi et al., 2015) and the beginning of thermal degradation.

Rice bran samples exhibited different thermal behavior among their respective cultivars (Figure 3b). BRS AG and BRS Pampa showed similar thermal behavior to each other, which differed from that of the BRS 358 cultivar. Derivative curves were generated (dTG) to better evaluate the thermal event characteristics of each sample. In rice brand TG curves of BRS AG and BRS Pampa, two main thermal events could be identified. The first was at
$220{ }^{\circ} \mathrm{C}$ and characterized by a mass loss of about $17 \%$, which could be related to initial moisture loss together with phytic acid degradation (Zhou, Ding, Qian, \& An, 2015). The second thermal event was observed at $310{ }^{\circ} \mathrm{C}$, characterizing the decomposition maximum temperature of the samples.

The thermal profile of rice bran from the BRS 358 cultivar presented at least three thermal events: the first was at a maximum degradation of approximately $75{ }^{\circ} \mathrm{C}$, related to the elimination of moisture; the second was at a maximum of approximately $240{ }^{\circ} \mathrm{C}$, related to the thermal degradation of protein and lipid fragments. As well as the thermal degradation of phytic acid, this event presents a more intense signal on dTG (figure 3c) when compared to the other crops studied due to the higher content of these components in the sample in 
question. Finally, pyrolysis of the glycosidic chains becomes a low-cost tool for the development occurred at a maximum of approximately $310^{\circ} \mathrm{C}$. of primary quality analysis and adulteration

Since the thermal behavior of rice and rice bran samples are different, the thermal analysis technique identification methodologies, mainly in derived products such as flours and other mixtures.
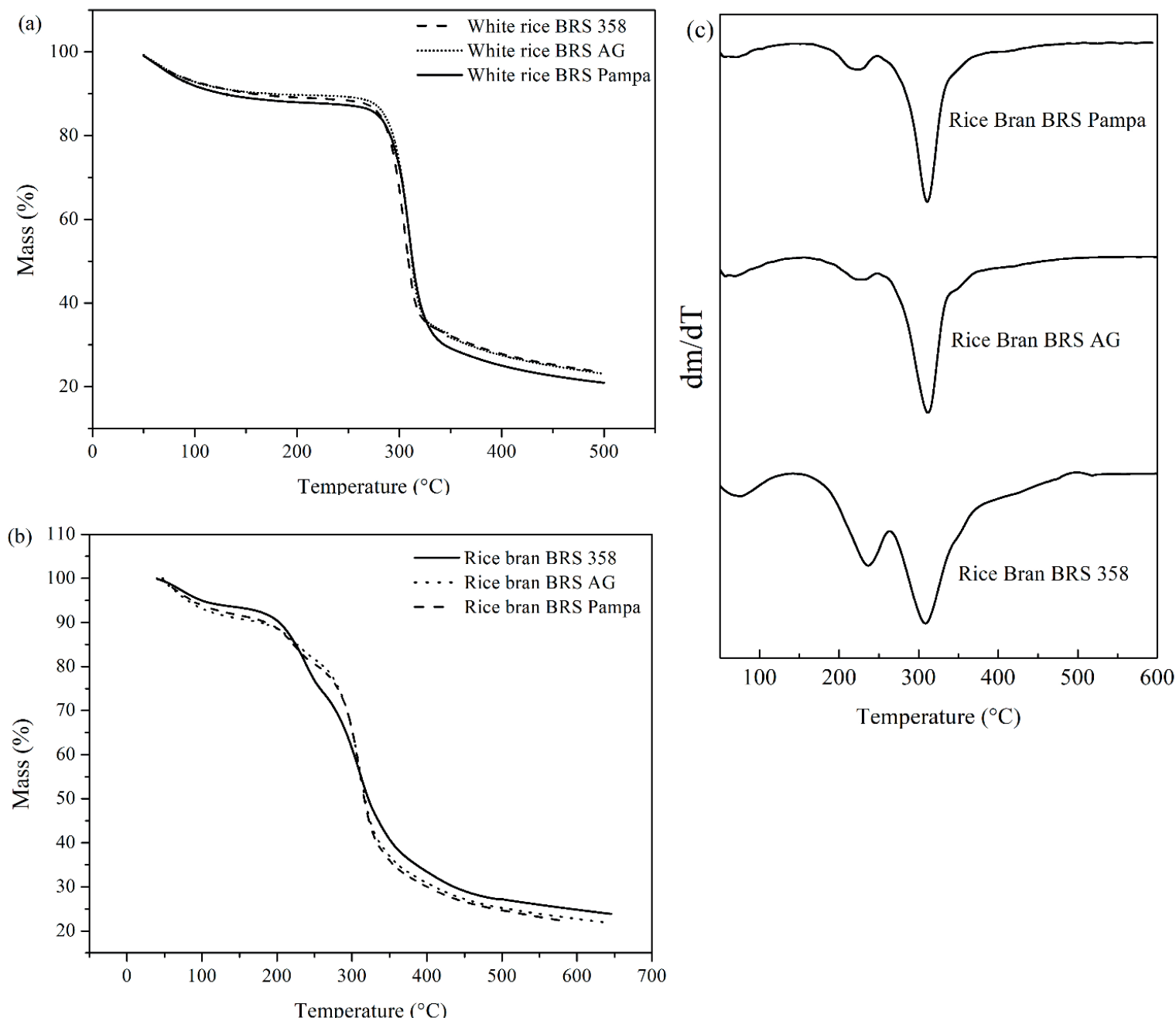

Figure 3. (a) Thermograms of white rice; (b) thermograms of rice bran; (c) derivative curves (dTG) of rice bran thermograms.

\section{Conclusion}

White rice from BRS AG, BRS Pampa, and BRS 350 cultivars exhibited similar moisture, lipid, and ash contents. BRS Pampa had the highest protein content, and BRS AG had the highest total carbohydrate content, confirming its excellent cooking properties and sources of fermentable carbohydrates for ethanol production, respectively.
In relation to rice bran samples, BRS 358 demonstrated the highest values of protein, lipids, and phytic acid and the lowest total carbohydrate content. When white rice samples were compared with their respective rice brans, the results demonstrated chemical compositions that differed among all cultivars studied, which was confirmed by FTIR-ATR and thermal analyses. 


\section{Acknowledgement}

The authors acknowledge the support of the Coordenação de Aperfeiçoamento de Pessoal de Nível Superior - Brasil (CAPES) - Finance Code 001, CNPq, Fundação Araucária, and Embrapa Clima Temperado.

\section{References}

Adu-Kwarteng, E., Ellis, W. O., Oduro, I., \& Manful, J. T. (2003). Rice grain quality: A comparison of local varieties with new varieties under study in Ghana. Food Control, 14(7), 507-514. doi: 10.1016/S09567135(03)00063-X

Amagliani, L., O’Regan, J., Kelly, A. L., \& O’Mahony, J. A. (2017). Composition and protein profile analysis of rice protein ingredients. Journal of Food Composition and Analysis, 59, 18-26. doi: 10. 1016/j. jfca.2016.12.026

Bagchi, T. B., Sharma, S., \& Chattopadhyay, K. (2016). Development of NIRS models to predict protein and amylose content of brown rice and proximate compositions of rice bran. Food Chemistry, 191, 2127. doi: 10.1016/j.foodchem.2015.05.038

Bhatnagar, A. S., Prabhakar, D. S., Prasanth Kumar, P. K., Raja Rajan, R. G., \& Gopala Krishna, A. G. (2014). Processing of commercial rice bran for the production of fat and nutraceutical rich rice brokens, rice germ and pure bran. LWT - Food Science and Technology, 58(1), 306-311. doi: 10.1016/j.lwt. 2014.03.011

Bragantini, C., \& Eifert, E. C. (2013). Secagem e beneficiamento. In C. M. Santiago, H. C. de P. Breseghello, \& C. M. Ferreira (Eds.), Arroz (2a ed., pp. 227-236). Brasília: EMBRAPA.

Canan, C., Cruz, F. T. L., Delaroza, F., Casagrande, R., Sarmento, C. P. M., Shimokomaki, M., \& Ida, E. I. (2011). Studies on the extraction and purification of phytic acid from rice bran. Journal of Food Composition and Analysis, 24(7), 1057-1063. doi: 10.1016/j.jfca.2010.12.014

Castro, A. P., Castro, E. M., \& Morais, O. P. (2013). Cultivares. In C. M. Santiago, H. C. de P. Breseghello, \& C. M. Ferreira (Eds.), Arroz (2a ed., pp. 75-88). Brasília: EMBRAPA.

Cheryan, M. (1980). Phytic acid interactions in food systems. Critical Reviews in Food Science and Nutrition, 13(4), 297-335.
Choi, Y. S., Choi, J. H., Han, D. J., Kim, H. Y., Lee, M. A., Kim, H. W.,... Kim, C. J. (2011). Effects of rice bran fiber on heat-induced gel prepared with pork saltsoluble meat proteins in model system. Meat Science, 88(1), 59-66. doi: 10.1016/j.meatsci.2010.12.003

Companhia Nacional de Abastecimento (2015). A cultura do arroz. Recuperado de https://www.conab. gov.br/outras-publicacoes/item/download/2523 efd93e81 ea2d9ae8f0302a6d4f9 ce fc6

Companhia Nacional de Abastecimento (2020). Acompanhamento da Safra Brasileira de Grãos. $5^{\circ}$ levantamento. Recuperado de https:/www.conab. gov.br/info-agro/safras/graos/boletim-da-safra-degraos

Demirci, T., Aktaş, K., Sözeri, D., Öztürk, H. İ., \& Akın, N. (2017). Rice bran improve probiotic viability in yoghurt and provide added antioxidative benefits. Journal of Functional Foods, 36, 396-403. doi: 10. 1016/j.jff.2017.07.019

Empresa Brasileira de Pesquisa Agropecuária (2015). EMBRAPA apresenta tecnologias na abertura da colheita do arroz. Recuperado de https://www. embrapa.br/busca-de-noticias/-/noticia/2472889/ embrapa-apresenta-tecnologias-na-abertura-dacolheita-do-arroz

Fan, D., Ma, W., Wang, L., Huang, J., Zhao, J., Zhang, H., \& Chen, W. (2012). Determination of structural changes in microwaved rice starch using Fourier transform infrared and Raman spectroscopy. Starch/ Staerke, 64(8), 598-606. doi: 10.1002/star.201100200

Favaro, L., Cagnin, L., Basaglia, M., Pizzocchero, V., van Zyl, W. H., \& Casella, S. (2017). Production of bioethanol from multiple waste streams of rice milling. Bioresource Technology, 244, 151-159. doi: 10.1016/j.biortech.2017.07.108

Fuster, J. M., Cortés, P. S, Bestard, J. P., \& Freixedas, F., G. (2017). Plant phosphates, phytate and pathological calcifications in chronic kidney disease. Nefrologia, 37(1), 20-28. doi: 10. 1016/j.nefroe.2017.01.018

Gomes, T. R., Carvalho, L. E., Freitas, E. R., Nepomuceno, R. C., Ellery, E. A. C., \& Rufino, R. H. M. (2012). Effect of inclusion of rice bran in diets for piglets from 21 to 42 days of age. Archivos de Zootecnia, 61(233), 1-10. doi: 10.4321/S000405922012000100014

Huang, Y. P., \& Lai, H. M. (2016). Bioactive compounds and antioxidative activity of colored rice bran. Journal of Food and Drug Analysis, 24(3), 564-574. doi: $10.1016 /$ j.jfda.2016.01.004 
Instituto Adolfo Lutz (2005). Métodos físico-químicos para alimentos (4a ed.). São Paulo: IAL.

Kaminski, T. A., Brackmann, A., Silva, L. P. da, Bender, A. B. B., \& Speroni, C. S. (2013). Composição química e alterações estruturais do arroz irrigado durante o armazenamento. Semina: Ciências Agrárias, 34(3), 1167-1184. doi: 10.5433/1679-0359.2013v34n $3 \mathrm{p} 1167$

Kim, S. M., Rico, C. W., Lee, S. C., \& Kang, M. Y. (2010). Modulatory effect of rice bran and phytic acid on glucose metabolism in high fat-fed C57BL/6N mice. Journal of Clinical Biochemistry and Nutrition, 42(1), 12-17. doi: 10.3164/jcbn.09-124

Liu, C., Yang, X., Wu, W., Long, Z., Xiao, H., Luo, F.,... Lin, Q. (2017a). Elaboration of curcuminloaded rice bran albumin nanoparticles formulation with increased in\&nbsp; vitro bioactivity and in\&nbsp;vivo bioavailability. Food Hydrocolloids, 77, 834-842. doi: 10.1016/j.foodhyd.2017.11.027

Liu, K. L., Zheng, J. B., \& Chen, F. S. (2017b). Relationships between degree of milling and loss of Vitamin B, minerals, and change in amino acid composition of brown rice. LWT - Food Science and Technology, 82, 429-436. doi: 10.1016/j. lwt.2017.04.067

Liu, Z. H., Cheng, F. M., Cheng, W. D., \& Zhang, G. P. (2005). Positional variations in phytic acid and protein content within a panicle of japonica rice. Journal of Cereal Science, 41(3), 297-303. doi: 10. 1016/j.jcs.2004.09.010

Martinez, A. P. C., Martinez, P. C. C., Souza, M. C., \& Brazaca, S. G. C. (2011). Chemical change in soybean grains with germination. Ciência $e$ Tecnologia de Alimentos, 31(1), 23-30. doi: 10.1590/ S0101-20612011000100004

Masunaga, T., Murao, N., Tateishi, H., Koga, R., Ohsugi, T., Otsuka, M., \& Fujita, M. (2019). Anti-cancer activity of the cell membrane-permeable phytic acid prodrug. Bioorganic Chemistry, 92, 103240. doi: 10.1016/j.bioorg.2019.103240

Michel, R. J. S., Jr., Canabarro, N. I., Alesio, C., Maleski, T., Laber, T., Sfalcin, P.,... Mazutti, M. A. (2016). Enzymatic saccharification and fermentation of rice processing residue for ethanol production at constant temperature. Biosystems Engineering, 142, 110-116. doi: 10.1016/j.biosystemseng.2015.12. 013

Moongngarm, A., Daomukda, N., \& Khumpika, S. (2012). Chemical compositions, phytochemicals, and antioxidant capacity of rice bran, rice bran layer, and rice germ. APCBEE Procedia, 2, 73-79. doi: 10.1016/j.apcbee.2012.06.014
Moro, J. D., Rosa, C. S., \& Hoelzel, S. C. S. M. (2004). Composição centesimal e ação antioxidante do farelo de arroz e seus benefícios à saúde. Revista Disciplinarum Scientia, Série: Ciência da Saúde, 4(1), 33-44.

Paraginski, R. T., Ziegler, V., Talhamento, A., Elias, M. C., \& Oliveira, M. (2014). Technological properties and cooking of rice grains conditioned at different. Brazilian Journal of Food Technology, 17(2), 146153. doi: 10.1590/bjft.2014.021

Qi, J., Yokoyama, W., Masamba, K. G., Majeed, H., Zhong, F., \& Li, Y. (2015). Structural and physicochemical properties of insoluble rice bran fiber: effect of acid-base induced modifications. RSC Advances, 5(97), 79915-79923. doi: 10.1039/c5ra15408a

Rafe, A., \& Sadeghian, A. (2017). Stabilization of Tarom and Domesiah cultivars rice bran: physicochemical, functional and nutritional properties. Journal of Cereal Science, 74, 64-71. doi: 10. 1016/j. jcs.2017.01.019

Rubens, P., \& Heremans, K. (2000). Stability diagram of rice starch as determined with FTIR. High Pressure Research, 19(1-6), 161-166. doi: $10.1080 / 08957950008202550$

Saw, N. K., Chow, K., Rao, P. N., \& Kavanagh, J. P. (2007). Effects of inositol hexaphosphate (phytate) on calcium binding, calcium oxalate crystallization and in vitro stone growth. Journal of Urology, 177(6), 2366-2370. doi: 10.1016/j.juro.2007.01.113

Scremin, F. R., Veiga, R. S., Silva-Buzanello, R. A., Becker-Algeri, T. A., Corso, M. P., Torquato, A. S.,... Canan, C. (2017). Synthesis and characterization of protein microcapsules for eugenol storage. Journal of Thermal Analysis and Calorimetry, 131, 653-660. doi: 10.1007/s10973-017-6302-8

Silva, E. O., \& Bracarense, A. P. F. R. L. (2016). Phytic acid: from antinutritional to multiple protection factor of organic systems. Journal of Food Science, 81(6), R1357-R1362. doi: 10.1111/1750-3841.13320

Silva, O. F. (2019a). Estatísticas de produção: arroz. Recuperado de http://www.agencia.cnptia. embrapa.br/gestor/arroz/arvore/CONT000fe 7457q 102wx5eo07qw4xezy8czjj.html

Silva, O. F. (2019b). Sócioeconomia: arroz e feijão. Recuperado de http://www.agencia.cnptia. embrapa.br/gestor/arroz/arvore/CONT000fe 7457q 102wx5eo07qw4xezy8czjj.html 
Silva, R. F., Ascheri, J. L. R., \& Pereira, R. G. F. A. (2007). Composição centesimal e perfil de aminoácidos de arroz e pó de café. Alimentos e Nutrição, 18(1), 325330 .

Smanalieva, J., Salieva, K., Borkoev, B., Windhab, E. J., \& Fischer, P. (2015). Investigation of changes in chemical composition and rheological properties of Kyrgyz rice cultivars (Ozgon rice) depending on long-termstack-storage after harvesting. LWT - Food Science and Technology, 63(1), 626-632. doi: 10. 1016/j.lwt.2015.03.045

Sociedade Nacional de Agricultura (2017). Qualidade do arroz brasileiro é diferencial para exportações. Recuperado de http://sna.agr.br/qualidade-do-arrozbrasileiro-e-diferencial-para-exportacoes/

Souza, A. M., Pereira, R. A, Yokoo, E. M., Levy, R. B., \& Sichieri, R. (2013). Alimentos mais consumidos no Brasil: Inquérito Nacional de Alimentação 20082009. Revista de Saúde Pública, 47(Supl. 1), 190199. doi: 10.1590/S0034-89102013000700005

Streck, N. A., Bosco, L. C., Michelon, S., Walter, L. C., \& Marcolin, E. (2006). Duração do ciclo de desenvolvimento de cultivares de arroz em função da emissão de folhas no colmo principal. Ciência Rural, 36(4), 1086-1093. doi: 10.1590/S010384782006000400007

Tran, U. T., Okadome, H., Murata, M., Homma, S., \& Ohtsubo, K. (2001). Comparison of vietnamese and japanese rice cultivars in terms of physicochemical properties. Food Science and Technology Research, 7(4), 323-330. doi: 10.3136/fstr.7.323
Walter, M., Marchezan, E., \& Avila, L. A. D. (2008). Rice: composition and nutritional characteristics. Ciência Rural, 38(4), 1184-1192. doi: 10.1590/ s0103-84782008000400049

Ying, D. Y., Hlaing, M. M., Lerisson, J., Pitts, K., Cheng, L., Sanguansri, L., \& Augustin, M. A. (2017). Physical properties and FTIR analysis of riceoat flour and maize-oat flour based extruded food products containing olive pomace. Food Research International, 100, 665-673. doi: 10.1016/j. foodres.2017.07.062

Zanão, C. F. P., Canniatti-Brazaca, S. G., Sarmento, S. B. S., \& Arthur, V. (2009). Efeito da irradiação gama nas características físico-químicas e sensoriais do arroz (Oryza sativa L.) e no desenvolvimento de Sitophilus oryzae L. Ciência e Tecnologia de Alimentos, 29(1), 46-55. doi: 10.1590/S0101-20612009000100008

Zhou, Q., Zhao, Y., Dang, H., Tang, Y., \& Zhang, B. (2019). Antibacterial effects of phytic acid against foodborne pathogens and investigation of its mode of action. Journal of Food Protection, 82(5), 826833. doi: 10.4315/0362-028X.JFP-18-418

Zhou, Y., Ding, C., Qian, X., \& An, X. (2015). Further improvement of flame retardancy of polyanilinedeposited paper composite through using phytic acid as dopant or co-dopant. Carbohydrate Polymers, 115, 670-676. doi: 10.1016/j.carbpol.2014.09.025 